\title{
A telemedicina alkalmazása a bőrgyógyászatban: a teledermatológia
}

\author{
Danis Judit ${ }^{1}$ - Forczek Erzsébet dr. $^{2}$ - Bari Ferenc dr. ${ }^{2}$ \\ Szegedi Tudományegyetem, Általános Orvostudományi Kar, ${ }^{1}$ Bőrgyógyászati és Allergológiai Klinika, \\ ${ }^{2}$ Orvosi Fizikai és Orvosi Informatikai Intézet, Szeged
}

\begin{abstract}
Az utóbbi évtizedek telekommunikációs és informatikai-technológiai fejlődése az egészségügyi ellátásban is jelentős változásokat hozott, és kialakult az orvostudomány új ága, a telemedicina. Az elmúlt 20 évben a telekommunikációs hálózatok folyamatos fejlődése, az internet megjelenése, az okostelefonok térhódítása lehetővé tette a telemedicina ugrásszerú fejlődését, így mára már számos eszköz és alkalmazás áll rendelkezésünkre, ezzel párhuzamosan pedig a szakirodalmi publikációk és hivatkozások száma is exponenciálisan növekszik. A terület egyik legdinamikusabban fejlődő ágává a teledermatológia, azaz a telemedicina bőrgyógyászati alkalmazása vált, mivel a bőrön található elváltozások jól láthatóak és hozzáférhetőek, az új eszközökkel pedig komolyabb beavatkozás nélkül is dokumentálhatóak. A módszer Magyarországon eddig még nem honosodott meg, pedig alkalmazásával a betegellátás hatékonyabbá, gyorsabbá és olcsóbbá válhat. A szerzők célja, hogy áttekintsék a bőrgyógyászat távkonzultációs gyakorlatának külföldi tapasztalatait és legfontosabb eredményeit. Kiemelik a teledermatológia jellegzetességeit, a vizsgálatok megbízhatóságát, a módszer ellátórendszerre gyakorolt hatását, valamint a szubjektív és objektív előnyöket és hátrányokat. Orv. Hetil., 2016, 157(10), 363-369.
\end{abstract}

Kulcsszavak: telemedicina, okostelefon, bőrgyógyászat, mobiltelefon-alkalmazás

\section{Telemedicine in dermatological practice: teledermatology}

Technological advances in the fields of information and telecommunication technologies have affected the health care system in the last decades, and lead to the emergence of a new discipline: telemedicine. The appearance and rise of internet and smart phones induced a rapid progression in telemedicine. Several new applications and mobile devices are published every hour even for medical purposes. Parallel to these changes in the technical fields, medical literature about telemedicine has grown rapidly. Due to its visual nature, dermatology is ideally suited to benefit from this new technology and teledermatology became one of the most dynamically evolving fields of telemedicine by now. Teledermatology is not routinely practiced in Hungary yet, however, it promises the health care system to become better, cheaper and faster, but we have to take notice on the experience and problems faced in teledermatologic applications so far, summarized in this review.

Keywords: telemedicine, smart phone, dermatology, mobile application

Danis, J., Forczek, E., Bari, F. [Telemedicine in dermatological practice: teledermatology]. Orv. Hetil., 2016, 157(10), 363-369.

(Beérkezett: 2015. november 26.; elfogadva: 2016. január 5.)

A számítástechnikai és telekommunikációs eszközök és rendszerek legújabb, egyik legdinamikusabban fejlődő alkalmazási területe az egészségügyben a telemedicina. A telemedicina - amelynek legfontosabb jellemzője, hogy az egészségügyi ellátás szereplői informatikai eszközök segítségével is érintkeznek egymással a diagnózis, a terápia, a rehabilitáció vagy a prevenció során - első és úttörő alkalmazója a XX. század elején a katonaság volt, ugyanis a távolban állomásozó alakulatok rádión keresztül kérhettek orvosi tanácsot vagy segítséget. Nagyobb fejlesztésekre pedig a század közepén, az első ûrutazások kapcsán került sor, mert szükséges volt az asztronauták életfunkcióinak folyamatos megfigyelése. A civilek ellátásában a telekommunikációs megoldásokat az 1980-as 
évek végétől alkalmazták egyre nagyobb mértékben, elsősorban a gyéren lakott és orvossal nem rendelkező területek ellátásának biztosítására [1]. Az alkalmazások sorában hamar megjelent a bőrgyógyászati távellátás, a teledermatológia fogalma is. A szakirodalomban az első sikeres alkalmazásokról Norvégiában és Oregon államban számoltak be $[2,3]$.

A teledermatológia térhódítását segíti, hogy a bőrön található elváltozások jól láthatóak, könnyen hozzáférhetőek. Dokumentálásuk nem igényel különlegesebb eszközparkot (lényegében csak egy fényképezőgépet - természetesen minél jobb felbontású, annál jobb), így a távellátás révén is megfelelő diagnózist lehet felállítani [4]. Technikailag elsőként a videotelefon biztosította a konzultáció és távvizsgálat lehetôségét, de a rossz képminőség miatt ez nem bizonyult kielégítőnek. Mára az informatikai szoftverek és fejlesztőeszközök használatának egyszerüsödése és a digitális kép- és hangkészítő készülékek árának folyamatos csökkenése lehetővé teszi a képek tömeges és kellő minőségű előállítását. A képkészítés egyszerű módszerei mellett a telekommunikációs eszközök és a könnyư internetes elérhetőség nyit utat a vizuális és verbális elemeket is ötvöző távoli, bőrgyógyászatban is felhasználható eszközrendszernek. Ezek közül elsősorban a mobil eszközök elterjedése hatott robbanásszerüen a telemedicina és a teledermatológia terjedésére, így ma már az okostelefonok jelenthetik az egyik leggyakrabban használt és megbízható összeköttetést az egészségügyben [5].

A teledermatológia tárgykörébe tartoznak mindazok az alkalmazások és eszközök, amelyeket használhatunk bőrgyógyászati diagnózis felállítására anélkül, hogy a beteg és az orvos személyes, fizikai kontaktusa létrejönne. Az eszközök és alkalmazások egy részét laikusok számára készítik, míg nagyobb részük a háziorvosok, illetve szakorvosok számára készül konzultációs célból. A fejlett országokban a telemedicina és a teledermatológia nagy népszerüségnek örvend, 2012-ben az amerikai kórházak mintegy felében már múködött valamilyen telemedicinális program [6]. Ugyan Magyarországon a teledermatológiai ellátás még nem honosult meg, az összefoglalónkban is bemutatott külföldi tanulmányok tapasztalatai elősegíthetik egy ilyen jellegű ellátórendszer megalkotását.

\section{A teledermatológiai alkalmazások technikai alapelvei}

A teledermatológiai alkalmazásoknál háromféle technikai alapelv érvényesülhet, amelyeket az irodalom a következőképpen határoz meg [1]:

1. Store-and-forward (tárolás és küldés): Az ezen az elven múködő alkalmazások a betegek adatait, tüneteinek leírását, illetve képeit tárolják és továbbítják a konzultációt végző orvosnak. Ezt a módszert már a kezdetektől alkalmazzák. A kiértékelő orvos a felvételek elkészítését követően, egy későbbi időpontban a továb- bított képek és leírások alapján állítja fel a diagnózist, és értesíti az érintett felhasználót az alkalmazáson keresztül. Ez a módszer lehetővé teszi a konzultációt orvos és orvos, illetve beteg és orvos között is, legyenek eltéró helyen, illetve eltérő időzónákban. A teledermatológiai alkalmazások általában ezt az elvet alkalmazzák, mivel a módszer során lehetőség van jó minőségű képek készítésére, amelyek lehetővé teszik a diagnosztizálást. A vizsgálat és a diagnózis térbeli és időbeli szétválása elősegíti az orvosi ellátást olyan helyeken, ahol nem elérhető valamilyen szakorvosi ellátás (például a bőrgyógyászat). Ugyanakkor nem lehetséges az azonnali reakció, a konzultációs válasz akár sokkal később érkezhet meg, mint a megkeresés, illetve többszöri megkeresésre is szükség lehet a komplett diagnózishoz, ha a tünetek leírása vagy az anamnézis nem komplett és nem lehet megbízható diagnózist felállítani.

2. Real-time (valós idejü): Általában videotelefonáláson alapuló konzultáció orvos és orvos vagy orvos és betege között. A store-and-forward módszerrel szemben sokkal jobban hasonlít egy hagyományos vizsgálathoz. Bár a résztvevők különböző helyen tartózkodnak, a közöttük létrejövő valós idejű kapcsolat lehetővé teszi a felmerülő kérdések azonnali tisztázását. Korábban a teledermatológiai konzultáció esetén a videó relatív rossz képminősége általában nem tette lehetővé a bőrelváltozások pontos diagnosztizálását, ezért ezt a módszert sokáig nem alkalmazták, de a módszer a videó képminőségének folyamatos javulása miatt egyre nagyobb teret nyer. E módszer révén a betegeknek nem szükséges messzire utazniuk a szakorvosi ellátásért, de mivel ugyanolyan előzetes időpont-egyeztetést igényel, mint a személyes konzultáció, a várólisták hosszát érezhetően nem csökkenti. Emellett megfelelő adatkapcsolat és számítástechnikai eszközpark szükséges a vizsgálathoz, ami korlátozza használatát.

3. Hybrid (kevert): Az előző két módszer egyesítése. Ez a módszer egyre kedveltebb a teledermatológiában, mivel a jó minőségű képekhez társulnak a valós idejü konzultációs kapcsolat előnyei. De itt is szükséges a korábbi időpont-egyeztetés, a megfelelő adatkapcsolat és számítástechnikai eszközpark.

\section{A teledermatológia alkalmazásának módszerei a betegellátásban}

A teledermatológiai betegellátás különböző modellek szerint történhet [7]:

1. Közvetlen betegellátás: A bőrgyógyász egyes teledermatológiai alkalmazásokon keresztül közvetlen teledermatológiai ellátásban részesítheti a pácienseket. Emellett egyes mútéteket vagy kezelést követően a betegek állapotának követésére is alkalmas a módszer. A szakirodalomban leírták a teledermatológia jelentőségét többek között krónikus sebek kezelése esetén [8], illetve egyes terápiák hatásának ellenőrzésére [9], csökkentve a szükséges személyes kontrollvizsgálatok számát. A telemedi- 
cina alkalmazásának bármelyik alapelve szerint történhet, általában a store-and-forward módszert alkalmazzák. Ma már számos mobilalkalmazás elérhető a piacon, amelyek kifejezetten a felhasználók, a páciensek számára készültek, és valódi konzultációt tesznek lehetővé. A mobileszközzel készített képeket és a tünetek leírását a program szakorvosoknak továbbítja, akik ezek alapján diagnózist és lehetséges kezelési módot javasolnak $[5,10,11]$. Magyarországon ezen alkalmazások használata ugyan lehetséges, de többségük jelenleg csak angol nyelven érhetó el, így ez korlátozza használatukat. Emellett az alkalmazás, illetve az alkalmankénti konzultáció ára körülbelül azonos a magánellátásban történő bőrgyógyászati konzultáció árával, ráadásul az országban jelenleg múködő biztosítási rendszerben ezek az alkalmazások egyelőre nem találtak megfelelő finanszírozási formát.

2. Előszürés: A bőrgyógyászok gyakran csupán előszúrésre használják a teledermatológiai rendszerbe feltöltött képeket, annak eldöntésére, hogy melyek azok a sürgős esetek, amelyek azonnali ellátásra szorulnak. Erre kivétel nélkül a store-and-forward alapelvet alkalmazzák.

3. Háziorvosi konzultáció: Az előző módszer kiegészítése lehet a háziorvos és a szakorvos között történő konzultáció a teledermatológia révén. A bőrgyógyász kezelési javaslatokkal segíti a háziorvos munkáját, ami történhet store-and-forward vagy real-time elrendezésben is.

4. Nem orvosi alkalmazások: A kiépített ellátórendszereken kívül általában böngészőkön keresztül, mobileszközökön megjelentek olyan alkalmazások is, amelyek nem orvosoknak készültek [5]. Ezeknek egy része oktatási célból készült, általában orvostanhallgatók és rezidensek számára, de laikusok is elérhetik [12, 13].

Olyan, kifejezetten a páciensek számára készült alkalmazások is elérhetőek a piacon, amelyek előre meghatározott algoritmusok alapján adnak kezelési tanácsokat [5]. Az alkalmazások többsége hivatalosan csupán oktatási célokat szolgál, mivel így nem kell orvosi szempontú ellenőrzés és akkreditáció az alkalmazások forgalomba hozatalához. Előnyük lehetne, hogy közvetlenül a betegnek adnak tanácsot, hátrányuk azonban, hogy a diagnózis hitelességéhez kétség férhet, ezáltal akár félrevezetők, esetenként veszélyesek is lehetnek. Erre példa, hogy az Amerikai Egyesült Államokban a Szövetségi Kereskedelmi Bizottság (FTC) két algoritmusalapú alkalmazást is betiltott az elmúlt évben, mivel az orvosi alkalmazásként megjelentetett MelApp és MoleDetective alkalmazásokról megállapítást nyert, hogy nem képesek a melanoma tüneteinek megállapítására [14]. Az ilyen alkalmazások felhasználása orvosilag nem javasolható, és leginkább csak arra korlátozódhat, hogy a személyes orvosi konzultációk között a betegek követhessék állapotuk változását fényképekkel, és a konzultációk alkalmával megmutathassák orvosuknak.

\section{A teledermatológiai ellátás jellemzői}

A teledermatológia alkalmazásának elsődleges célja, hogy azok számára is biztosítható legyen a bőrgyógyászati ellátás, akiknek a lakhelyükön nincs lehetőség ellátásra. Ezzel a módszerrel tehát növekedhet az ellátott betegek száma, csökkenthető a páciensek utazási ideje és költsége, illetve a sürgősen személyes konzultációt igénylő betegek kiszűrhetőek. Ezen alapelv szerint múködik a teledermatológiai ellátórendszer a Feröer-szigetek és az anyaország, Dánia között [15], nagy sikerrel. Napjainkban azonban szélesebb körü célt határoznak meg az irodalomban, amely szerint mindenki számára elérhetővé kell tenni a teledermatológiai ellátást, így létrehozva egy jobb, gyorsabb és olcsóbb ellátási rendszert [1].

Az orvosi gyakorlatba a teledermatológiai ellátást leginkább a háziorvos és a bőrgyógyász közötti konzultációként lehet beépíteni, elsőként azokban a régiókban, ahol bőrgyógyászhiány van. Ezek a teledermatológiai konzultációk általában store-and-forward alapelven müködnek. A háziorvos (vagy egy megfelelően képzett aszszisztens) a bőrelváltozásról képeket készít és esetleírással együtt továbbítja a bőrgyógyásznak. A szakorvos diagnózist készít, kezelési javaslatot nyújt, szükség esetén pedig személyes bőrgyógyászati ellátást javasol [4]. Ilyen jellegü ellátórendszer kiépítéséről számos tanulmány készült, többek között Ausztráliában [16, 17], az Egyesült Királyságban [18-23], az Egyesült Államokban [24, 25], Hollandiában [26, 27], Spanyolországban [28], Szaúd-Arábiában [29], Új-Zélandon [30] és a harmadik világbeli országokban $[31,32]$. A különböző tanulmányok a helyi viszonyoktól is függően különböző kérdésekre keresték a választ, de a legtöbb a gazdasági kérdéseket és kényelmi szempontokat veszi figyelembe.

\section{A teledermatológiai konzultáció idōigénye}

Átlagosan egy teledermatológiai konzultáció a háziorvosnál 11-15 percet vesz igénybe, majd a bőrgyógyászok további $12-15$ percet töltenek a rendszerbe beérkező esetek kiértékelésével [21, 26, 30]. Mindkét esetben a konzultációk időigénye nagymértékben függ az informatikai környezet kiépítettségétől és az orvosok rutinjától is. A háziorvosnál egyrészt a képkészítés és a képek feltöltése vehet el sok időt (5-15 percet), másrészt az online konzultációs felület kitöltésének ideje a rendszerek integrációjának függvénye (ebből a szempontból az internetkapcsolat minősége is meghatározó), amely igencsak változó az egyes tanulmányokban. A háziorvosok gyakran hiányolják a háziorvosi rendszerek összekötését a konzultációs rendszerrel, arra panaszkodnak, hogy a praxis digitális rendszerébe felvitt adatokat ismételten fel kell vinniük a telekonzultációs rendszerbe is $[21,26,30]$. Részben a környezeti hiányosságok következtében, a szakorvosok munkáját is gyakran nehezítik a 
gyenge minőségű képek, a nem kellően kitöltött online konzultációs felületek és a betegek egyéni kórtörténetének a hiánya.

A beteg szempontjából a másik időtényező a bőrgyógyász válaszának beérkezése. A fejlett országokban a store-and-forward rendszerekben 2-4 óra, amíg a bőrgyógyász válaszol. A fejlődő országok esetén egy nap és egy hét között változik a válasz beérkezéséig eltelt idő. Az eltelt idő nagyságánál figyelembe kell venni az időeltolódást is, mivel a konzultációs partner általában fejlett országbeli orvos [30, 33].

Figyelemre méltó egy kaliforniai vizsgálat is [25], amelynek során azt tapasztalták, hogy a teledermatológiai konzultáció esetén több mint egy hónappal csökkent az elsődleges diagnózis felállításához szükséges idő, a szükséges biopszia elvégzésére 19 nappal korábban került sor, míg a daganat mútéti eltávolítása átlagosan 21 nappal hamarabb történt meg, mint a hagyományos módon ellátott betegek esetében, valamint a beavatkozást megelőző szakorvosi konzultációk száma is csökkent. A távkonzultáció betegekre gyakorolt pozitív hatása, hogy a szakorvosi vizsgálatok számának csökkenésével a várakozási idő is csökkenhet, ezzel párhuzamosan hamarabb sor kerülhet a szükséges beavatkozásokra, ami a rosszindulatú elváltozások esetén jelentősen növelheti a túlélést.

\section{A teledermatológia gazdaságossági jellemzôi}

A fejlett országokban a legfontosabb gazdasági kérdés, hogy a virtuális konzultációk révén csökkenthető-e a személyes bőrgyógyászati vizsgálatok száma. Egy Nagy-Britanniában végzett vizsgálat is mutatja, hogy miután a háziorvosok az általuk potenciálisan veszélyesnek ítélt elváltozásokról készített képeket teledermatológiai konzultációra küldték, a betegek 75\%-a nem igényelt szakorvosi ellátást, akiket a hagyományos ellátórendszerben bőrgyógyászatra utaltak volna, így tehát jelentősen csökkent a személyes szakorvosi vizsgálatok száma [23]. Más tanulmányok adatai is azt mutatják, hogy az ilyen módon vizsgált esetek kétharmadában nem utalja tovább a háziorvos a betegeket bőrgyógyászhoz [33]. Előfordulhat azonban, hogy a teledermatológia olyan népszerúvé válik a betegek körében, hogy a háziorvosi praxist a szükségesnél többen keresik fel, ahogy azt Ford és Pereira is tapasztalták [22].

\section{A diagnózisok megbizhatósága}

A fentebbi, fóleg gazdasági és kényelmi szempontú kérdések mellett a teledermatológia alkalmazásának legfontosabb szempontja az adható diagnózis pontossága. Számos klinikai kutatás vizsgálta a teledermatológia orvosi alkalmazásának megbízhatóságát [1, 8, 28, 33, 34-38].

A diagnózis megbízhatóságának ellenőrzésére többféle módszert alkalmaznak. Az első módszerben ugyanaz a bőrgyógyász teledermatológia révén, majd személyesen is diagnosztizálja ugyanazt a beteget [36]. Az esetek egyharmadában a bőrgyógyászok a teledermatológiai konzultáció esetén nem tudtak megfelelő diagnózist biztosítani, amiért a nem megfelelő minőségü és mennyiségű információ felelős. A teledermatológiai módszerrel diagnosztizálható betegek esetén a diagnózis megbízhatósága 90\%-os volt. Edison és mtsai módszere szerint [34] minden pácienst háromszor vizsgáltak meg másmás orvosok: egyszer személyesen, egyszer store-andforward módszerrel és egyszer valós idejű konzultáció során. Azt tapasztalták, hogy a különböző orvosok által felállított store-and-forward telemedicina esetén 73\%-os a diagnózis egyezése a személyes konzultációval, míg valós idejú konzultáció esetén ennél magasabb, mintegy $80 \%$. Ehhez hasonlóan a különböző orvosok által adott személyes és teledermatológiai módszerrel készült diagnózis megbízhatóságát vizsgálták egy olaszországi tanulmányban is, ahol 91\%-os megbízhatóságot tapasztaltak [39]. A tanulmányok azt mutatják, hogy a különböző elváltozások esetén különböző a diagnózis megbízhatósága: gyulladásos kórképek esetén 75\%-os a diagnózis megbízhatósága [28], a gyermekbőrgyógyászat [36] terén is $80 \%$-os megbízhatóságot tapasztaltak, míg pigmentált laesiók diagnosztizálása esetén körülbelül 75\%os a diagnózisok megbízhatósága $[37,38]$.

A fentiek alapján látható, hogy a diagnózis megbízhatósága különböző faktoroktól függ, így befolyásolja a konzultáció alapelve és a vizsgált bőrelváltozások típusa is, de a készített képek minősége szintén meghatározó. Általában úgy tekintik, hogy a teledermatológiai diagnózisok megbízhatósága, azaz hogy két vagy több független vizsgáló által megállapított diagnózis azonos lesz, megközelíti a személyes konzultáció megbízhatóságát $[1,35]$. Alapvetően minél alacsonyabb a teledermatológiai ellátás megbízhatósága, annál nagyobb számú beteget kell beutalni a teledermatológiai konzultáció után személyes bőrgyógyászati vizsgálatra, duplán terhelve az ellátórendszert.

\section{A teledermatológia sikerét meghatározó tényezők}

Az előzőek alapján látható, hogy a teledermatológiai ellátás diagnosztikai megbízhatósága és az ellátórendszer gazdaságossága szorosan összefügg egymással. Egy alacsony diagnosztikai megbízhatóságú teledermatológiai ellátórendszer csak feleslegesen terheli a betegellátást, túl sok beteg személyes szakorvosi vizsgálatára van szükség a bizonytalan diagnózis miatt, így nem csökken a közvetlen személyes konzultációk száma. Landow és mtai [33] gyưjiötték össze a klinikai vizsgálatok eredményei alapján azokat a tényezőket, amelyek megalapozzák a teledermatológiai ellátás sikerességét. Ezeknek a tényezőknek az ismerete elengedhetetlen a megbízható, jól múködő teledermatológiai ellátórendszer kiépítéséhez:

Az ellátás minőségét meghatározó legfontosabb tényező a készített képek minősége [33]. A tapasztalatok 
szerint, a pontos diagnózis felállításához megfelelő eszközzel és képzett személy által készített képek szükségesek $[7,33]$, amit a digitális dermatoszkóppal készített képek még tovább tudnak javítani [40]. A háziorvosok eszközei közé általában nem tartozik a dermatoszkóp, és nincsenek felkészítve ennek használatára sem. Ennek következtében, egy jól múködő teledermatológiai konzultációs rendszer kiépítéséhez elsődleges a háziorvosok felkészítése az eszközök használatára és a jó minőségú információk továbbítására, valamint a bőrgyógyászok kiképzése a diagnózis felállítására képek és leírások alapján [7, 28]. Az orvosok továbbképzésének lehetséges következménye a konzultációra küldött vizsgálatok, és a további vizsgálatra behívott betegek számának csökkenése is. Azokban az esetekben, ahol a felesleges vizsgálatok számát nem sikerül lecsökkenteni, ott a teledermatológiai rendszer kiépítése pluszfeladatokkal is terheli a meglévő egészségügyi rendszert [33], ezért a képzés elengedhetetlen fontosságú.

A másik meghatározó tényező az orvosok és a betegek megfelelő (és lelkes) hozzáállása a vizsgálatokhoz. A tanulmányokban leírtak nagy részében a háziorvosok önkéntes alapon vehettek részt, így természetes a lelkesedésük, és a nehézségek ellenére is többnyire pozitív a véleményük az ellátórendszerről [22, 26, 30]. A 2000-es évek első felében készült vizsgálatokból azonban az ellenkezőjére is találunk példát [16, 19]. Az ausztráliai vizsgálatokban a megkeresett orvosok mindössze negyede vett részt aktívan. A vizsgálatban részt venni nem kívánó orvosok általában a digitális kamera beszerzésének költségére, a fotók készítésének, illetve a konzultációs nyomtatvány kitöltésének az idejére, valamint az ezekkel kapcsolatos extra munkára hivatkoztak. Emellett, azok az orvosok, akik eleve magasnak érzik a munkaterhelésüket, kevésbé lelkesednek egy ilyen jellegű ellátórendszerért [26].

\section{A teledermatológia megitélése}

A teledermatológia szubjektív megítélése általában mind a betegek, mind az orvosok körében pozitív [1, 8, 28]. A betegek szempontjából kényelmes ez a fajta távellátás, időt, energiát és pénzt spórolnak a felesleges utazás elhagyásával, és elégedettek az ellátás minőségével.

A vizsgálatokban részt vevő háziorvosok mind egyetértettek abban, hogy az ilyen jellegü teledermatológiai konzultációs rendszer legnagyobb személyes hozadéka számukra a rendszer oktatási jellege [21, 22, 26, 27, 30]. A részt vevő háziorvosok a konzultációk révén biztosabbak lettek a diagnózisokban a szakorvosi visszacsatolás következtében, így ezzel párhuzamosan csökkent részükról a konzultációs igény [27], ami a szakorvosnak továbbküldött esetek számát hosszú távon folyamatosan csökkenti.

\section{A teledermatológia alkalmazásának problémái}

A tapasztalatok azt mutatják, hogy a teledermatológiai ellátórendszerek múködése nem mindig megfelelő, és nem váltják be teljesen a hozzájuk füzött reményeket: az ellátás nem lesz számottevően gyorsabb és olcsóbb sem $[33,41]$. Ma még a teledermatológiai konzultáció után is túl sok beteget feleslegesen beküldenek a szakorvosi vizsgálatra, holott ellátásuk a háziorvos által is megoldható lenne. Egy jól múködő teledermatológiai ellátórendszerben csak a súlyos vagy veszélyeztetett betegek személyes szakorvosi vizsgálata történik meg, de ehhez a távkonzultációs rendszer megfelelő kiépítésére és a szakszemélyzet kiképezésére van szükség [33].

Az ellátórendszer nem megfelelő múködésén kívül számos technikai, anyagi, jogi és etikai kérdés vetődik fel mind a teledermatológiai ellátórendszer kiépítésével, mind a páciensek számára készült konzultációs alkalmazások használatával kapcsolatban [42]. A teledermatológia jelenlegi ellátórendszerbe integrálása általában csak a klinikai kutatások idejére valósul meg, ezért nincsenek hosszú távú tapasztalatok [28], nem megoldottak sem a finanszírozási, sem az infrastrukturális, sem pedig a személyi kérdések. Jelenleg az orvosok a napi feladataik mellett láthatják el a teledermatológiai konzultációt, ami pluszterhet ró rájuk, az egészségbiztosítás pedig általában nem terjed ki a távellátásra még a fejlett országokban sem.

A teledermatológiai ellátás során készített dokumentumok tárolása és továbbítása betegjogi kérdéseket is felvet $[28,42]$. Az adatok küldése nem történhet e-mail üzenetek által, mivel az nem tekinthető informatikailag biztonságosnak, ezért egy megfelelően kiépített, védett rendszert kell létrehozni erre a célra. Külön kérdést vet fel a mobilalkalmazások kezelése, például a korábbi esetek fényképeinek, adatainak tárolása, amelyek az összehasonlíthatóságot biztosítanák, de ugyanakkor ezek is sérthetik az érintett betegek jogait.

Etikai szempontból felvetődik, hogy egy teledermatológiai rendszerben elszemélytelenedik a kapcsolat a beteg és az orvos között, aminek megelőzésére a megfelelő kommunikáció elengedhetetlen [42]. Ugyanakkor ennek a kérdésnek a megválaszolására még nem rendelkezünk elegendő adattal, az sem bizonyított, hogy a hybrid vagy a real-time rendszerek milyen mértékben tudják pótolni a hagyományos beteg-orvos kapcsolatot.

A tanulmány nem részletezte, de komoly kutatási és gyógyítási hozománya is lehet a távkonzultáció során keletkező adatoknak. Minden eddiginél sokkal jobban dokumentált paraméterek állhatnak rendelkezésre a konzultációs folyamatok során, amelyek egy megfelelően előkészített informatikai környezetben gyưjthetők és feldolgozhatók lennének. Az így keletkezett nagyszámú 
betegadatot nyilvántartó adatbázisok lehetőséget adnának a betegségekkel és azok lefolyásával kapcsolatos új összefüggések felfedezésének, amelyek eredménye azonnal visszacsatolható lenne a betegek személyre szabottabb gyógyításában.

A telemedicina, ezen belül a teledermatológia alkalmazásának szükségessége ma már egyértelmúnek tûnik. A sikeresség inkább a problémák elhárításának módjától függ, ahol ezek a kezdeti tapasztalatok jelenthetik az alapját a hosszú távon fenntartható rendszer kiépítésének.

\section{Következtetések}

A trendek és előrejelzések azt mutatják, hogy a jövőben elkerülhetetlen lesz a telemedicina alkalmazása a betegellátásban, ami a várakozások szerint javítani fogja az ellátás hatékonyságát, gyorsaságát. A technika kiépítéséhez szükséges anyagi ráfordítások pedig a felesleges vizsgálatok számának csökkenésével rövid idő alatt megtérülhetnek. Emellett a teledermatológia magában hordozza a betegségek kezdeti stádiumban való felismerését, csökkentve az ellátás költségét, növelve a betegek túlélésének esélyét.

A vizsgálatok szerint a telemedicina, ezen belül is a teledermatológiai ellátás szubjektív megítélése pozitív. A betegek szempontjából kényelmes ez a fajta távellátás, időt, energiát és pénzt spórolnak a felesleges utazás elhagyásával, és elégedettek az ellátás minőségével.

A jövőben egy olyan ellátási modell megalkotása szükséges, amelyben a hagyományos és a teledermatológiai ellátórendszer szoros együttmúködése is megvalósulhat. Technikailag egy ilyen ellátórendszer kiépítéséhez minden lehetőség adott, de alkalmazása a környezet körültekintő tervezését és az ellátószemélyzet képzését is feltételezi. A körültekintő tervezés és a megfelelő informatikai háttér biztosíthatja, hogy a teledermatológiai ellátórendszer kiépítése ne rójon már induláskor sem jelentős pluszterheket az ellátókra.

Anyagi támogatás: A közlemény megírása anyagi támogatásban nem részesült.

Szerzői munkamegosztás: A szerzők közösen írták a kéziratot. A cikk végleges változatát mindhárom szerző elolvasta és jóváhagyta.

Érdekeltségek: A szerző́knek nincsenek érdekeltségeik.

\section{Köszönetnyilvánítás}

Köszönettel tartozunk Kemény Lajos professzor úrnak, amiért a kézira tot elolvasta, értékelte és hasznos tanácsaival segítette munkánkat.

\section{Irodalom}

[1] Coates, S. J., Kvedar, J., Granstein, R. D.: Teledermatology: From historical perspective to emerging techniques of the modern era. Part I: History, rationale, and current practice. J. Am. Acad. Dermatol., 2015, 72(4), 563-574.

[2] Vorland, L. H.: Good experiences with telemedicine in the regional hospital of Tromsø. Nord. Med., 1992, 107(10), 241243. [Article in Norwegian]

[3] Perednia, D. A., Brown, N. A.: Teledermatology: one application of telemedicine. Bull. Med. Libr. Assoc., 1995, 83(1), 42-47.

[4] Lenardis, M. A., Solomon, R. S., Leung, F. H.: Store-and-forward teledermatology: a case report. BMC Res. Notes, 2014, 7, 588.

[5] Brewer, A. C., Endly, D. C., Henley, J., et al.: Mobile applications in dermatology. JAMA Dermatol., 2013, 149(11), 1300-1304.

[6] Kahn, J. M.: Virtual visits - confronting the challenges of telemedicine. N. Engl. J. Med., 2015, 372(18), 1684-1685.

[7] Armstrong, A. W., Kwong, M. W., Ledo, L., et al.: Practice models and challenges in teledermatology: a study of collective experiences from teledermatologists. PLoS ONE, 2011, 6(12), e28687.

[8] Zarchi, K., Haugaard, V. B., Dufour, D. N., et al.: Expert advice provided through telemedicine improves healing of chronic wounds: Prospective cluster controlled study. J. Invest. Dermatol., 2015, 135(3), 895-900.

[9] Oostveen, A. M., Beulens, C. A., van de Kerkhof, P. C., et al.: The effectiveness and safety of short-contact dithranol therapy in paediatric psoriasis: a prospective comparison of regular day care and day care with telemedicine. Br. J. Dermatol., 2014, 170(2), 454457.

[10] Schopf, T. R., Bolle, R., Solvoll, T.: The workload of web-based consultations with atopic eczema patients at home. BMC Res. Notes, 2010, 3, 71.

[11] Peart, J. M., Kovarik, C.: Direct-to-patient teledermatology practices. J. Am. Acad. Dermatol., 2015, 72(5), 907-909.

[12] American Academy of Dermatology: Dermatology A-Z. 2012. https://www.aad.org/dermatology-a-to-z

[13] Dermatology in review. 2014. http://dermatologyinreview. $\mathrm{com} / \mathrm{merz}$

[14] Federal Trade Commission: FTC cracks down on marketers of "melanoma detection" apps. 2015. https://www.ftc.gov/newsevents/press-releases/2015/02/ftc-cracks-down-marketersmelanoma-detection-apps

[15] Jemec, G. B. E., Heidenheim, M., Dam, T. N., et al.: Teledermatology on the Faroe Islands. Int. J. Dermatol., 2008, 47(9), 891-893.

[16] See, A., Lim, A. C., Le, K., et al.: Operational teledermatology in Broken Hill, rural Australia. Australas. J. Dermatol., 2005, 46(3), 144-149.

[17] Hockey, A. D., Wootton, R., Casey, T.: Trial of low-cost teledermatology in primary care. J. Telemed. Telecare, 2004, 10(Suppl. 1), 44-47.

[18] Wootton, R., Bloomer, S. E., Corbett, R., et al.: Multicentre randomised control trial comparing real time teledermatology with conventional outpatient dermatological care: societal cost-benefit analysis. BMJ, 2000, 320(7244), 1252-1256.

[19] Collins, K., Bowns, I., Walters, S.: General practitioners' perceptions of asynchronous telemedicine in a randomized controlled trial of teledermatology. J. Telemed. Telecare, 2004, 10(2), 9498.

[20] Finch, T. L., Mair, F. S., May, C. R.: Teledermatology in the U. K.: Lessons in service innovation. Br. J. Dermatol., 2007, 156(3), 521-527.

[21] Thind, C. K., Brooker, I., Ormerod, A. D.: Teledermatology: A tool for remote supervision of a general practitioner with spe- 
cial interest in dermatology. Clin. Exp. Dermatol., 2011, 36(5), 489-494.

[22] Ford, J. A., Pereira, A.: Does teledermatology reduces secondary care referrals and is it acceptable to patients and doctors?: a service evaluation. J. Eval. Clin. Pract., 2015, 21(4), 710-716.

[23] Griffiths, W. A.: Improving melanoma diagnosis in primary care - a tele-dermatoscopy project. J. Telemed. Telecare, 2010, 16(4), 185-186.

[24] Armstrong, A. W., Wu, J., Kovarik, C. L., et al.: State of teledermatology programs in the United States. J. Am. Acad. Dermatol., 2012, 67(5), 939-944.

[25] Hsiao, J. L., Oh, D. H.: The impact of store-and-forward teledermatology on skin cancer diagnosis and treatment. J. Am. Acad. Dermatol., 2008, 59(2), 260-267.

[26] Berghout, R. M., Eminović, N., de Keizer, N. F., et al.: Evaluation of general practitioner's time investment during a store-andforward teledermatology consultation. Int. J. Med. Inform., 2007, 76(Suppl. 3), S384-S391.

[27] Van der Heijden, J. P., de Keizer, N. F., Bos, J. D., et al.: Teledermatology applied following patient selection by general practitioners in daily practice improves efficiency and quality of care at lower cost. Br. J. Dermatol., 2011, 165(5), 1058-1065.

[28] Lasierra, N., Alesanco, A., Gilaberte, ., et al.: Lessons learned after a three-year store and forward teledermatology experience using internet: Strengths and limitations. Int. J. Med. Inform., 2012, 81(5), 332-343.

[29] Kaliyadan, F., Amin, T. T., Kuruvilla, J., et al.: Mobile teledermatology - patient satisfaction, diagnostic and management concordance, and factors affecting patient refusal to participate in Saudi Arabia. J. Telemed. Telecare, 2013, 19(6), 315-319.

[30] McGoey, S. T., Oakley, A., Rademaker, M.: Waikato teledermatology: a pilot project for improving access in New Zealand. J. Telemed. Telecare, 2015, 21(7), 414-419.

[31] Nair, A. R., Nair, P. A.: Teledermatology: a possible reality in rural India. Int. J. Dermatol., 2015, 54(3), 375-376.

[32] Delaigue, S., Morand, J. J., Olson, D., et al.: Teledermatology in low-resource settings: the MSF experience with a multilingual tele-expertise platform. Front. Public Health, 2014, 2, 233.

[33] Landow, S. M., Mateus, A., Korgavkar, K., et al.: Teledermatology: Key factors associated with reducing face-to-face dermatology visits. J. Am. Acad. Dermatol., 2014, 71(3), 570-576.
[34] Edison, K. E., Ward, D. S., Dyer, J. A., et al.: Diagnosis, diagnostic confidence, and management concordance in live-interactive and store-and-forward teledermatology compared to in-person examination. Telemed. J. E Health, 2008, 14(9), 889-895.

[35] Pak, H., Triplett, C. A., Lindquist, J. H., et al.: Store-and-forward teledermatology results in similar clinical outcomes to conventional clinic-based care. J. Telemed. Telecare, 2007, 13(1), 2630.

[36] Heffner, V. A., Lyon, V. B., Broussean, D. C., et al.: Store-andforward teledermatology versus in-person visits: A comparison in pediatric teledermatology clinic. J. Am. Acad. Dermatol., 2009, 60(6), 956-961.

[37] Warshaw, E. M., Gravely, A. A., Nelson D. B.: Reliability of store and forward teledermatology for skin neoplasms. J. Am. Acad. Dermatol., 2015, 72(3), 426-435.

[38] Bowns, I. R., Collins, K., Walters, S. J., et al.: Telemedicine in dermatology: a randomised controlled trial. Health Technol. Assess., 2006, 10(43), iii-iv, ix-xi, 1-39.

[39] Nami, N., Massone, C., Rubegni, P., et al.: Concordance and time estimation of store-and-forward mobile teledermatology compared to classical face-to-face consultation. Acta Derm. Venereol., 2015, 95(1), 35-39.

[40] Şenel, E., Baba, M., Durdu, M.: The contribution of teledermatoscopy to the diagnosis and management of non-melanocytic skin tumours. J. Telemed. Telecare, 2013, 19(1), 60-63.

[41] Pak, H. S., Datta, S. K., Triplett, C. A., et al.: Cost minimization analysis of a store-and-forward teledermatology consult system. Telemed. J. E Health, 2009, 15(2), 160-165.

[42] Coates, S. J., Kvedar, J., Granstein, R. D.: Teledermatology: From historical perspective to emerging techniques of the modern era. Part II: Emerging technologies in teledermatology, limitations and future directions. J. Am. Acad. Dermatol., 2015, $72(4), 577-586$

(Danis Judit

Szeged, Korányi fasor 6., 6720 e-mail: danis.judit@med.u-szeged.hu)

Az Orvosi Hetilap egyes számai megvásárolhatók a Mediprint Orvosi Könyvesboltban.

Cím: Budapest V., Múzeum krt. 17. - Telefon: 317-4948 